\title{
Morgue of the Misbegotten: O'Neill's Pattern of Salvation in The Iceman Cometh
}

\author{
Mufeed F. Al-Abdullah
}

\section{(2) OpenEdition \\ Journals}

Édition électronique

URL : https://journals.openedition.org/ejas/1166

DOI : 10.4000/ejas. 1166

ISSN : 1991-9336

Éditeur

European Association for American Studies

Référence électronique

Mufeed F. Al-Abdullah, « Morgue of the Misbegotten: O'Neill's Pattern of Salvation in The Iceman Cometh », European journal of American studies [En ligne], 2-1 | 2007, document 4, mis en ligne le 04 avril 2007, consulté le 08 juillet 2021. URL : http://journals.openedition.org/ejas/1166 ; DOI : https:// doi.org/10.4000/ejas. 1166

Ce document a été généré automatiquement le 8 juillet 2021.

Creative Commons License 


\title{
Morgue of the Misbegotten: O'Neill's Pattern of Salvation in The Iceman Cometh
}

\author{
Mufeed F. Al-Abdullah
}

1 Eugene O'Neill's play, The Iceman Cometh (1939), dramatizes a pessimistic vision of a godless world, inhabited by misbegotten beings, in which life is a nightmare and death is the only way out. O'Neill in The Iceman Cometh has moved even beyond Nietzsche's contention that God is dead, to demonstrate that we cannot create another one, not even in fiction. O'Neill explains:

It is really the first play of a trilogy that will dig at the roots of the sickness of today as I feel it - the death of an old God and the failure of science and materialism to give any satisfying new one for the surviving primitive religious instinct to find a meaning for life in, and to comfort its fears of death with (O'Neill in Clark 120).

2 The world, for O'Neill, has become a wasteland in which there is nowhere to go, and nothing is worth having. Like Ibsen in The Wild Duck, O'Neill dramatizes "the human condition as such that man cannot live without clinging to some illusion of life-lie" (Frenz 79). O'Neill portrays man as "too frail to withstand the stark truth of reality and must, in order to survive, renounce in favor of self-delusion" (Frenz 82). In The Iceman Cometh, O'Neill has exceeded Ibsen, Gorky, Strindberg and the Greeks in his depiction of the pitiable condition of mankind. Louis Broussard views the play as "a negating epilogue" to O'Neill's somewhat optimistic play, Days without End, and holds that “it is a refutation of every trace of optimism that appears earlier in his plays" (Broussard 30).

3 The play goes beyond expressing O'Neill's bleak vision of modern life to stress the futility of any hope of reformation in our times. It dramatizes O'Neill's lack faith in the efficacy of saviors or reformers. O'Neill's self-appointed savior is presented as an antisavior, under whose spell the "contented" characters become no more than walking corpses that wander in an icy hell (Bogard 415).

4 This paper aims to analyze the pattern of reformation O'Neill uses in order to put together his pessimistic vision. O'Neill's dramatic pattern serves as the medium that 
enables the playwright to convey his message in the play effectively. The pattern in question includes three elements: (1) the subjects of reformation (the characters); (2) the topos, which is the arena of reformation; and (3) the reformer; who is devoted to converting the subjects to his doctrine or vision. The dramatic action of the play is devoted to the interaction of the reformer with his subjects in an isolated playfield. Indeed, The Iceman Cometh is woven around the efforts of Theodore Hickman (Hickey), the reformer, who endeavors to impose his doctrine, or vision of life, upon the group of jaded characters, the subjects of reformation, who happen to gather in the isolated Harry Hope's Saloon, the topos of reformation.

The divine-like presence of the reformer makes the topos mysterious and gives mystery to his interaction with his subjects. Gathering the subjects or patients in an isolated location is necessary for the process of healing because it enables the reformer to cut his patients off from their social and environmental circumstances, which in effect are the source of their ailments and disorders. The isolation and alienation of the patients enable the healer to purge them of their former identities and give them new ones, enlightening and regenerating them. Under the spell of the reformer, the characters are supposed to undergo a journey from birth to rebirth, from degeneration to regeneration, from depravity to righteousness. Having been empowered with the ability to forge healthy relationships in a harmonious society, the recovered characters are allowed to reintegrate into society.

6 Furthermore, O'Neill expands the meaning of the play by providing it with symbolic and cosmopolitan significance. O'Neill's reformer symbolically appears on the scene like a deus-ex-machina, a celestial messenger, or a savior; who comes into the world heralding a message from external spheres that is meant to guide mankind out of desperation and depravity. Hickey, however, proves to be not a savior or a redeemer, but rather a parody of a savior, alienating, rather than saving, the fallen community of man.

7 A number of critics contrast Hickey with Jesus Christ. They are encouraged to do so by the religious symbolism O'Neill builds into the play, whose very title points to Hickey as a foil to the bridegroom, Christ, who "cometh" to reunite with his church. The sharp contrast between Hickey and Christ is repeatedly emphasized within the context of striking similarities: both have twelve disciples; both hold last suppers for their disciples; both are capable of miraculous deeds (Hickey could raise the dead and turn liquor into water).

8 But why does O'Neill invite the comparison? The answer is that by paralleling Hickey and Christ, the playwright ultimately intends a contrast. In the midst of the similarities, the differences are carefully and consciously defined. Thus, O'Neill depicts Hickey's mission as seemingly messianic only to remind us of its disastrous nature. Cyrus Day's commentary on the contrast between Christ's and Hickey's missions is illuminating. Day argues:

In the symbolism of theology, the bridegroom is always Christ, giver of life eternal. Waiting for the bridegroom symbolizes man's hope of redemption. Union with the bridegroom signifies victory over death and salvation in the world to come. Union with the iceman, conceived as adultery, must, then, be a parody of union with the bridegroom, and signify surrender to death and acquiescence in personal annihilation. Evelyn Hickman, after her husband kills her, finds the peace of oblivion in the arms of the symbolical iceman. The other characters in the play will eventually find the same kind of peace when they abandon their illusory hope of 
happiness, whether here and now on earth, or in a hypothetical Christian hereafter (Day5). chooses to overlook, the serious misery of life and existence. Hickey, their deluded reformer, serves as the reminder who wishes to open the eyes of his pals to see their agony, or rather to embarrass them by forcing their eyes to open and see the stark reality of their lives.

13 The roomers spend their ample, but idle, time flattering their host, cadging drinks, endlessly repeating anecdotes of past stories, and repeatedly promising to go back to their past jobs. They clearly live in the past or the future, but never in the present. Their vision of the past is a highly colored cosmetic view. Thus, the bar becomes their place of "pipe dreams" (p. 42), a waiting room for a better tomorrow. Many of them seem to have a great faith in "tomorrow" and have the illusion that everything will happen then. Tomorrow, each will go back to his past job; tomorrow, Hickey will come; tomorrow, Hope will have a stroll around the ward; tomorrow, they will pay their rent, and so on. This faith in a better tomorrow frees the characters from the present, as they keep procrastinating and putting off what they ought to do. Larry Slade, perhaps the only character free from this illusion about tomorrow, comments:

They've all a touching credulity concerning tomorrows... It'll be a great day for them, tomorrow - the feast of All Fools, with brass bands playing! Their ships will 
come in loaded to the gunwales with cancelled regrets and promises fulfilled and

clean slates and new laces! (9) dreams. They have subsistence because, as Larry informs us, once in a while, one of them "makes a successful touch somewhere," others "get a few dollars from past connections that pay them on the condition they never come back" (35). As for the rest, they live on free lunches and drinks from Harry Hope, who does not care about expenses as long as he likes his customers. This is why most of them spend their time flattering Hope and paying him compliments. They have become hypocrites and liars in order to guarantee their survival. They also wait for Hickey, an old friend of Hope's, who comes periodically to celebrate Hope's birthday. He buys them drinks, tells them jokes, and gives them money. Timothy Wiles describes these lost characters as follows:

These pals of Harry spend their days cadging drinks, flattering their host, and rationalizing their failures in the professional world 'through endless repetition of their pipe dreams and life stories. They form a surrogate family of brotherly pals, fatherly elders, and mothering tarts, who crave to spend all their time together [.

. .]. Harry's "family" is a localized phenomenon as well as a "family of man (Wiles 181). in an atmosphere that has the effect of healing past enmities. For instance, Wetjoen and Lewis, mortal enemies in the Boer War, have become "bosom pals" (35) since they met in the bar. Despite the variety of the inmates' backgrounds and outlooks, "they appear strikingly alike in their inability to face the grim present and their tendency to dote upon a glorious past or hope for a promising future" (Tornquist 224). Army; Piet Wetjoen (The General), a one-time leader of Boer commandos; Ed Mosher, a one-time circus man; Pat McGloin, a one-time police lieutenant; James Cameron (Jimmy Tomorrow), a one-time correspondent for an English paper during the Boer War; Joe Mott, a one-time proprietor of a gambling house; Hugo Kalmar, a one-time editor of anarchist periodicals; Larry Slade, a one-time syndicalist anarchist; Willie Oban, a onetime Harvard law student; Rocky Pioggi, night bartender; Chuck, the day bartender; and Pearl, Margie and Cora, streetwalkers. These characters come from a variety of ethnic and national origins: Irish, Scottish, Slavic, Negro, English, Italian, and South African. The inclusion of this wide variety of ethnic origins justifies Timothy Wiles' description of Hope's family as a "family of man." In fact, this variety gives the play a cosmic flavor.

The arena of reforming these derelicts is Harry Hope's saloon, which is detached and isolated from the world. It is the last harbor for the group of life's castaways and dropouts. In that saloon, Hope acts as host to the group. In one of his angry fits, Hope refers to his saloon as an "asylum for bums and crooks," "hookers," and "anarchist tramps." (145). ii

Hope's saloon is a peaceful shelter for its tenants. In fact, it is a "place of retirement" (28) in which the characters are never disturbed.iii Even the police ignore it because 
"they think it's harmless as a graveyard" (25). Indeed, its regulars are mesmerized in a state between death and life, a limbo in which they experience death-in-life. The safety and peace of the bar derive from the passivity of the regulars who have already withdrawn from life into seclusion and dreams.

Hope's place, however, is not recreational (in any sense of the word). It looks like a dusty and cold warehouse or a morgue. It is the last harbor for the group of moribund lost sheep. They resort to it only to wait for death. Larry Slade aptly describes it as follows:

It's the No Chance Saloon. It's Bedrock Bar, The End of the Line Cafe. The Bottom of the Sea Rathskeller! Don't you notice the beautiful calm in the atmosphere? That's because it's the last harbor [...]. No one here has to worry about where they're going next, because there is no further they can go. It's a great comfort to them. Although even here they keep up the appearance of life with a few harmless pipe dreams about their yesterdays and tomorrows (25).

Hope's hotel seems odd as "[w]orst is best here, and East is West, and tomorrow is yesterday"(44). In other words, everything in the bar is topsy-turvy. Though a victim of a misconception, Hickey is genuine in his belief that he can bring happiness to his friends if they cooperate with him. However, the characters do not cooperate with their would-be savior. Thus, the savior finds it necessary to have his patients undergo manipulated experience meant to guarantee positive results. Hickey's mission is launched against the false dreams of his pals, which, he believes, are the source of their misery.

Hickey benefits from his knowledge of his friends and the nature of their problems. "He claims that he knows everyone of them inside and out by heart" (147). Therefore, he is motivated to change their lives by his concern and care for them. Their lives in the bar, rendered invalid by liquor and elusive dreams, push him to intervene in order to help them.

O'Neill has his savior don the mask of a stranger in order to have advantage over his patients. By changing his usual habits and conduct, Hickey appears to his pals as a stranger. This way, he alienates himself from the patients he hopes to redeem. Instead, however, he disqualifies himself as an effective influence on them. Instead of reuniting with his community, he estranges himself from it. Moreover, Hickey's challenge to the desires of his friends belittles his ability and reduces his chances to render any change. To work against the wishes of the community is a usual duty of saviors and social reformers because reforming a group of people means re-channeling the direction of their lives and practices.

Hickey's mission thus fails for two major reasons. Firstly, the very ideal he calls for is simply erroneous; it is neither revivifying nor gratifying for the characters by any means. Secondly, Hickey does not succeed in making converts among his patients. His only source of power or magic is his "persuasive convincingness," his salesmanship (76).

Hickey uses the technique of alienation as a means of preparing the bar regulars to accept his new mission. Alienation in The Iceman Cometh is achieved through the atmosphere of tension and suspense created by Hickey's deliberate change of his accustomed behavior and by the sudden alteration of his habits. He clearly wants to prepare the pals for accepting him in his new role, hoping to eliminate from their minds their previous image of him as a fellow drunkard. 

Hickey is

A hard-ware drummer, an old friend of Harry Hope's and all the gang. He's a grand guy. He comes here twice a year regularly on a periodical drunk and blows in all his money (24). Obviously, the play includes two Hickeys: the old Hickey and the new Hickey, The old

This Hickey is a dream for the characters in the bar. Joe says: "I was dreamin' Hickey come in de door, crackin' one of dem drummer's jokes, wavin' a big bankroll, and we was all goin' drunk for two weeks" (18).

The periodic visits of this old Hickey are usually accompanied by a festive atmosphere producing a sort of revival on the occasion of Hope's birthday. Old Hickey's humor and jokes are appreciated and much talked about by his pals. Hope relishes in "a good laugh with old Hickey ...[who can) make a cat laugh" (61). Larry admits that "Hickey's a great one to make a joke of everything and cheer you up" (13). Rocky reports how Hickey usually makes a gag about his wife, "when he's cockeyed cryin' over her picture and den sprinigin' it on yuh all of a sudden dat he left her in de hay wid de iceman" (13). The usual ceremonial and humorous atmosphere makes the characters wait for Hickey's arrival "wid their tongues hangin' out a yard long" (74).

Significantly, this old Hickey is only talked about by the characters, but he never shows up in the play. The Hickey we meet is the new one who assumes the role of the reformer. This Hickey arrives late, is not funny but rather grim and sober, and does not come to celebrate Hope's party by drinking, but to sell the characters a stern spiritual hardware. Moreover, and unexpectedly, Hickey, the "prophet," comes to his community sleepy and exhausted, when he should be enthusiastic and completely alert. This weakness hampers his efforts and interrupts his sermon.

This transformation in the personality and concerns of the reformer can be noticed in the evolution of Hickey, who has changed through his personal experience and wants his pals to follow his pattern of reformation, thinking that they will then be happy, as he believes himself to be. From the beginning, Hickey warns that he has just finished "figurin out de best way to save dem and bring dem peace" (74). The bar regulars, who know Hickey only as a humorous drinking pal, brush this warning aside as one of Hickey's jokes or tricks.

31 Hope, with some foolish enthusiasm, expresses their attitude and yearning to see Hickey: “Tell him we're waitin' to be saved" (75). And, as for Hickey's reported sobriety, another of Hickey's tricks, Hope sets forth a counter-trick:

Well, bejees, he won't be sober long! He'll be good and ripe for my birthday party tonight at twelve. ...Listen! He's fixed some new gag to pull on us. We'll pretend to let him kid us, see? And we'll kid the pants off him (75).

Clearly, the characters, who build their lives around illusions and dreams, refuse to accept or recognize the new reality of Hickey; they feel rather satisfied to think of him as an old pal. The old Hickey becomes part of their pipe dreams, their illusion of happiness. Hickey's first encounter with his pals creates speculation, uneasiness, concern, and probably humiliation on their part.

Hickey confuses his pals by acting contrary to his normal habits. He comes to the bar sleepy and exhausted, does not drink, does not pull a gag about his wife and the iceman, neither does he pass Evelyn's picture around. 

"prophet" is required to persuade his sales-resistant barroom audience of the usefulness of his merchandise (Muchnic 124). He himself is involved in what he preaches, by releasing himself from the pipe dream that had made his life miserable. Thinking that he has attained salvation, Hickey has quit his hedonistic life of drinking and women. He wants his friends to share with him the "grand feeling" (85) he enjoys. He wants them to realize their dreams of tomorrow. His aim is clearly not to lead them to success, but to release them from their illusions, so that they will be able to accept their status quo without guilt or remorse. He preaches:

You can let go of yourself at last. Let yourself sink down to the bottom of the sea. Rest in peace. There's no farther you have to go. Not a single damned hope or dream left to nag you. (86)

In the same vein, he adds later: "You'll be in a today where there is no yesterday or tomorrow to worry you. You wont give a damn what you are any more" (147-48). iv 

bughouse preachin', and quits tellin yuh where yuh get off, he's de same old Hickey" (110). Hickey's approach to the characters makes him a menace, a "pest," or a ghost haunting them from one room to another, and finally haunts them out of the bar. Rocky warns Margie and Pearl not to believe in Hickey's preaching: “Don't let Hickey put no ideas in your nuts if you wanta stay healthy" (97-8). The more Hickey interacts with his patients, the more he loses control over them and the more he alienates himself from their community. That is because his creed condemns their style of life and threatens to shatter their community in Hope's bar, which is the last and only resort they think they have. They even refuse to drink liquor, their only means of creating a false illusion of happiness in the lower depths of Hope's saloon. Rocky reports:

All de gang sneakin' upstairs, leavin' free booze and eats like dey was poison! [...] He's been hoppin' from room to room all night. Yuh can't stop him. He's got his reform wave goin' strong dis mornin'! (157)

Even those who cannot stop drinking maintain that Hickey owes them the drinks in recompense for listening to him. Joe, for instance, argues that he "earned all de drinks on him [Hickey] for listening to his crazy bull" (109). He, however, insists that he will never accept Hickey as a drinking pal again (109). Larry, too, says, "He owes it to me" (182).

The self-deluded bar regulars can only walk away from liquor as they feel their very passive existence threatened and their survival at stake. McGloin, for instance, is shivering lest Hickey convince Harry to take the much-talked-about walk around the ward. He explains: "Once Bessie's relations get their hooks in him, it'll be as tough for us as if she wasn't gone" (132). Mosher, too, is afraid that Harry might give up on them:

Harry'll mosey around the ward, dropping in on everybody who knew him [...]. (Indignantly) And they'll all give him a phony hand and a ton of good advice about what a sucker he is to stand for us (132).

During Hope's birthday party, the gap between the characters and their self-created savior widens tremendously. With no control over them, Hickey resorts to his "magical" rhetoric in order to bridge the gap between himself and his patients. Hickey repeatedly promises peace and happiness, and ends up offering them only death and

European journal of American studies, 2-1 | 2007 
misery. Hickey aspires only to convince, rather than to exert his vision upon his pals. Therefore, he appeals to their interests and needs.

Hickey's speech during the celebration of Hope's party is typical of all his speeches in the play. As usual, he emphasizes his friendship with his pals and expresses his concern for their happiness. It also includes an appeal to the desires of the listeners, and recognizes the difficulty of their experience, promising them happiness and peace if they cooperate and follow his instructions:

Do you suppose I'd deliberately set out to get under everyone's skin and put myself in dutch with all my old pals, if I wasn't certain, from my own experience, that it means contentment in the end for all of you? (117).

Instead of being an act of persuasion, Hickey's speech becomes an apology and an explanation for "the rough stuff" he has to pull on them (147), for his intervention, and for his creating problems among his friends. He reminds them of his qualities as the old Hickey, who never interfered in their affairs. He justifies his actions as being motivated only by his concern for their happiness. He is a reformer and has to use every available means to carry out his mission. He adds that he could have worked with each of his pals individually since he knows everyone of them "inside and out, by heart" (147); however, he explains, he has no time, because he is "slated to leave on a trip" soon (147). Hickey wants to shift the emphasis of the dreaming characters from illusions about yesterday and tomorrow to an acceptance of failure in a continuous present. The result, Hickey argues, will ultimately be valuable:
After you're rid of the damned guilt that makes you lie to yourselves you're something you're not, and the remorse that nags at you and makes you hide behind lousy pipe dreams about tomorrow, you'll be in a today where there is no yesterday or tomorrow to worry you. You won't give a damn what you are any more. This peace is real! It's a fact! I know! Because I've got it! Here! Now! Right in front of you! You see the difference in me (147-48).

Hickey believes that he has found truth and enlightenment, which he wishes to pass on to his friends. He is unaware that the peace he wants to sell them is the peace of death. Nor does he realize that what he trusts to be his personal salvation is no more than another pipe dream, an illusion. Hickey fails to understand that his audience are aware of the idleness of their dreams and that they still lie to themselves in order to make up for their past failures. Therefore, his speech and rhetoric will not change anything. Naturally, then, the characters take revenge upon Hickey and puncture the effect of his highly eloquent speech with taunting remarks.

Hickey not only preaches a disastrous gospel and shows a hazardous misunderstanding of his potential disciples, but he also uses an ineffective and inappropriate tactic to talk the bar regulars into buying it. He is weak and hesitant in selling his gospel. He is vague and wishes, like Hamlet, "By indirections find directions out" (II. i. 66). Rocky complains: "He don't really tell yuh. He just keeps hintin' around” (97).

As for the birthday party itself, Hickey tricks the characters by asking the bartenders to set out the glasses; then spoils the festive atmosphere by only drinking his chaser. Hickey does not come this time to gratify the characters' need for an orgiastic drinking bout, but to teach a stern creed. Why, then, does he stage a conventional birthday party, with cakes, candles, flowers, champagne, and presents, arrangements which are unprecedented in the bar? This is understandable, since everything Hickey does this time is different from what he usually does. However, there seems no point to the whole party if Hickey is there only to preach his new gospel. Perhaps he feels that, 
through offering a substitute for the usual drinking ceremony, he can ensure control over his pals. The normal annual drinking party imposes the only pattern on the aimless lives of the bums in the bar. The new conventional party indicates a sort of revivalism and renewal in those characters' lives, which is what Hickey means it to be:

I hope today will be the biggest day in your life, and in the lives of everyone here, the beginning of a new life of peace and contentment where no pipe dreams can ever nag at you (144).

51 To this, Hickey drinks alone, for none of the roomers accepts his version of peace. Even when the characters leave the bar, each pretending that he wants to realize his dreams tomorrow, they merely do so to escape the bullying Hickey. He turns their quiet saloon into a "madhouse" (184). McGloin explains: "I'd rather sleep in the gutter than pass another night under the same roof with that loon, Hickey" (185). Cora draws Chuck out of the bar to escape from Hickey: "Let's get started before he comes down"(185).

Hickey's persistence pushes the characters out of the bar, and results in a defiant hatred of him and of his gospel. Rocky suggests that "Dat louse Hickey oughta be croaked" (187). Hickey is unable to accurately predict the results of his experiment. His misplaced confidence stems entirely from the revelatory act of shooting his wife, which he considers to be the means to his salvation. He fails to recognize that the shock the characters get from the experience is not temporary and will not give them the peace he predicts. He thinks that this is merely a momentary condition, as he has learned from his own experience:

of course it hit me, too, but only for a minute. Then I felt as if a ton of guilt had been lifted off my mind. I saw what had happened was the only possible way for peace of all concerned (203).

The real effect of Hickey's experiment is best described by Rocky:

What he's done to Harry. Jees, de poor old slob is so licked he can't even get drunk. And all de gang. Dey're all licked. I couldn't help feelin' sorry for de poor bums when dey showed up tonight, one by one, lookin' like pooches wid deir tails between deir legs, dat everyone'd been kickin' till dey was too punch- drunk to feel it no more .... Jees, dere ain't enough guts left in de whole gang to battle a mosquito (216).

Contrary to all Hickey's expectations, the characters do not attain any peace or happiness, and he is frustrated at their failure to reform:

Don't you know you're free now to be yourselves, without having to feel remorse or guilt, or lie to yourselves about reforming tomorrow? Can't you see there's no tomorrow now? You're rid of it forever. You've killed it. You don't have to care a damn about anything anymore (225).

The characters are, finally, not free, and the pastor fails to reform his lost sheep through the sort of peace he has given to Evelyn. He, like his characters, is the victim of a pipe dream and consoles himself by accounting for his failure as the result of his friends' hatred of him.

At the end, Hickey loses his confidence and becomes weaker than his patients. Larry comments: "He's lost his confidence that the peace he's sold us is the real McCoy, and it's made him uneasy about his own. He'll have to prove to us-" (223).

Indeed, Hickey is defeated and "has lost his beaming salesman's grin." His manner is no longer self-assured. His expression becomes "uneasy, baffled, and resentful" (223). These changes in Hickey's personality indicate, in his striking moment of recognition, that the peace he has gained by murdering his wife is, in fact, only another pipe dream. 
It is at this point that Hickey is free from self-delusion, and it is also at this point, as life reveals its agonizing realities with the absence of illusions, that he accepts death. Death becomes the only alternative for Hickey's self-assertion. Thus, he calls the detectives to come and take him because he does not "give a damn" about his life anymore. Hickey becomes weaker than his pals, and instead of having them confess to him, he confesses to them. His confession comes as a satisfaction for his approach and an explanation of his failure:

I'm certain if I tell you about it from the beginning you'll appreciate what I've done for you and why I did it, and how damned grateful you ought to be instead of hating me. (232) realization that his newly found truth is just his pipe dream, his illusion. Hickey's belief that he has achieved personal salvation proves to be another of his self-delusions, demonstrating that he has never attained enlightenment. He is unqualified for the
redemption of others, preaching selfishness as a way to happiness. He even rebels demonstrating that he has never attained enlightenment. He is unqualified for the
redemption of others, preaching selfishness as a way to happiness. He even rebels confused motives. He has never attained any personal salvation; rather, he has passed from one self-delusion to another. He has first rebelled against the stern Puritanism of his father, a "hellfire preacher," who used to sell the Hoosiers "nothing for something" (232). For Hickey, "Home was like jail, and so was school, and so was that damned hick town" (232). In his rush of antagonism to his father's fanaticism, Hickey has developed a sense of appreciation for hedonistic life. He has escaped from home to inhabit bars and pool rooms where he could smoke, drink, and meet hookers (232).

In the meantime, Hickey has found in the ideal love of Evelyn, the daughter of a respectable and wealthy family, a substitute for both Puritanism and hedonism. Yet, in time, this ideal love has also proved illusory. Marriage to Evelyn has never solved Hickey's problems: he "never could learn to handle temptation" (2.35). Evelyn's "sweetness and love and pity and forgiveness" (238) have proved destructive to the already emotionally torn Hickey. He claims that he has always been torn between the desire to be faithful and the need to meet other women during his travels. He has always suffered from his inability to be himself without being ashamed (236). Evelyn's constant forgiveness has turned him into a "guilty and ashamed skunk" (238). His soul has been divided between loving her fidelity and devotion and hating her as a reminder of his imperfection and misery.

Ultimately, Hickey shows that his love for Evelyn is a facade behind which hide his hatred and repugnance of her and of the ideal love she represents. His hatred of Evelyn has resulted from her kindness, which in turn makes him hate his own deficiency. He explains that her forgiveness "made me hate myself all the more. You'd never believe I could hate so much" (239).

Hickey's inability to live up to the standards embodied by Evelyn has crucially shaken his self-confidence and shattered his ego. From Hickey's point of view, Evelyn is an impediment to his peace and happiness. Her constant forgiveness and kindness turn to be the source of turbulence and disorder in Hickey's life. Thus convinced, Hickey gets rid of Evelyn, thinking that he will achieve personal salvation. Murdering his wife, Hickey rejoices at removing a great obstacle that has always threatened his unending quest for self-assertion, annihilating the pipe dreams. ${ }^{\mathrm{vi}}$

It is only when, at the end, he slips and says he hated Evelyn that he himself gains some 
against altruism by murdering his wife, who stands for "self-denying, devotion, and forgiveness" (Scheibler 169).

At the end of The Iceman Cometh, Hickey clings desperately to his pipe dream; confessing even his own madness to prevent himself from facing the truth about his illusions and feelings toward Evelyn: "Yes, Harry, of course, I've been out of my mind ever since! All the time I've been here! You saw I was insane, didn't you?" (243).

Hickey continues to resist his own enlightenment, regretting even coming to Hope's bar. He considers his endeavors a waste of time and effort and is frustrated by his friends' betrayal of him. "It was a waste of time coming here," shouts Hickey.

For the roomers, Hickey proves not only a criminal but also a fool. Larry pities his foolishness for revealing his secret:

You mad fool, can't you keep your mouth shut. We may hate you for what you've done, here this time, but we remember the old times, too, when you brought kindness and laughter instead of death! We don't want to know things that will make us help send you to the chair (227).

The dichotomy between the good old Hickey and the criminal new Hickey is clear at last. Hope decides to forget the new Hickey and remembers only the old pal: "We'll forget that and only remember him the way we've always known him before - the kindest, biggest-hearted guy ever wore shoe leather" (251).

The old pal brought peace of some sort to his friends; the new one comes with "the peace of death" (103). Hickey's association and even equation with death is prevalent throughout the play. Larry, early in the play, calls him "the Great Nihilist" who has "started a movement that'll blow up the world" (104), and "Death was the Iceman Hickey called to his home" (183). The characters refrain from drinking the liquor he brings them because they feel as if Hickey "was the Iceman of Death himself treating" (182). The new Hickey is also associated with bad omens and is the source of nightmares. Joe contends: "Bad luck come in de door when Hickey come" (169). He also causes Hugo to have "bad dreams" (249).

Indeed, the experience the new Hickey has the characters undergo is a nightmare that interrupts their infinite sleep. They are released from his haunting nightmare only when the detectives take him to the Chair of Death. Hickey's departure is accompanied by the recession of his ideology to the background, and by the return of his pals to their normal aimless course as liquor regains its potent, yet soothing, effect. In the play, everyone remains reaffirming the old life of Harry Hope's saloon. Hickey's pals "return to their orgiastic drinking to bring back the illusions lost in the one bout with reality" (Broussard 30). All but Larry and Parritt, Hickey's only converts: "For them there remains only self-destruction, the quick kind, a little more violent and sudden than the death awaiting the others" (Clark 156).

Hickey, Parritt, and Larry form a community of death: the first two realize that death is their way out of the agony of life depleted of pipe dreams. Larry, however, is different: he believes that he is free from any pipe dream and is waiting for death: "I'm the only real convert to death Hickey made here," declares Larry. He differs from Hickey and Parritt in that, unlike them, he does not commit suicide, but is rather waiting for death to come. The other characters make up the community of life. They choose to cling to life with their eyes closed rather than accept death with their eyes open. They are happy as "Hickey or Death" leaves them because they do not feel like dying anymore (49). 

sole function is the termination of human life and the negation of spiritual values. The salvation Hickey peddles is thus anti-Christian and antithetical to death by crucifixion, which serves as the Christian means by which eternal peace in the hereafter is attained. O'Neill's play is thus a venture into death, darkness and pessimism. It capitalizes on the devastation and depravity of modern Man, and allows for no possibility of salvation or saviors. It offers no hope, but plays an elegy for the misbegotten and shows the world as a morgue for the dead-in-life.

\section{BIBLIOGRAPHIE}

\section{WORKS CITED}

Alexander, Doris. The Tempering of Eugene O'Neill. New York: Harcourt, Brace \& World, inc., 1962.

Bentley, Eric. Theatre of War. New York: The Viking Press, 1954.

Bogard, Travis. Contour in Time. The Plays of Eugene O'Neill. New York: Oxford University Press 1972.

Brustein, Robert. The Theatre of Revolt. Boston: Brown and Company, 1962.

Cajelan, Brother. “The Pendulum Starts Back.” Catholic World 140. March 1935.

Chabrowe, David. “Dionysus in The Iceman Cometh.” Modern Drama 4 (1962): 377-88.

Clark, Barrett H. Eugene O’Neill. New York: Robert M. McBride \& Company, 1926.

Day, Cyrus. “The Iceman and the Bridegroom.” Modern Drama (May 1958).

Edyvean, Alfred R. This Dramatic. World: Using Contemporary Drama in the Church. New York:

Friendship Press, 1970.

Falk, Doris V. Eugene O'Neill and the Tragic Tension: An Interpretive Study of the Plays. New Brunswick, N.J.: Rutgers University Press, 1958.

Fleche Anne. Mimetic Disillusion: Eugene O'Neill, Tennessee Williams, and U.S. Dramatic Realism.

Tuscaloosa: University of Alabama Press, 1997.

Frenz, Horst. Eugene O’Neill. Trans. Helen Sebba. New York: Ungar, 1971.

Gilder, Rosamond. "The Iceman Cometh." O'Neill and His Plays: Four Decades of Criticism. Eds. Oscar Cargill, N. Bryllion Fagin, William J. Fisher. New York: New York University Press, 1961. 212-13.

Kahn, Sy. “O'Neill's Legion of Losers in The Iceman Cometh.” The Forties: Fiction, Poetry, Drama. Ed. Warren French. Deland, Fla..: Everette Edwards, Inc., 1969.

Miliora, Maria T. Narcissism, The Family, and Madness: A Self-Psychological Study of Eugene O'Neill and His Plays. New York: Peter Lang, 2000.

Muchnic, Helen. “The Irrelevancy of Belief: The Iceman Cometh and the Lower Depths." O'Neil and His Plays: Four Decades of Criticism. Eds. Oscar Cargill, N. Bryllion Fagin, William J. Fisher. New York: New York University Press, 1961. 
O'Neill, Eugene. The Iceman Cometh. New York: Vintage Books,

Parks, Edd Winfield. “Eugene O'Neill's Quest.” The Tulane Drama Review 4 (March 1960): 99-107.

Raleigh, John Henry. The Plays of Eugene O'Neill. Carbondale: Southern Illinois University Press, 1965.

---, ed.: Twentieth Century Interpretations of The Iceman Cometh: A Collection of Critical Essays.

Englewood Cliff: Prentice-Hall, Inc., 1968.

Scheibler, Rolf. Late Plays of Eugene O'Neill. Bern: Francke Verlag, 1970.

Sheaffer, Louis. : O'Neill: Son and Artist. Boston: Little, Brown and Company, 1973.

---: O'Neill; Son and Playwright. Boston: Little, Brown and Company, 1968.

Tiusanen, Timo. O' Neill's Scenic Images. Princeton, N.J.: Princeton University Press, 1968.

Tornquist, Egil. A Drama of Souls: Studies in O'Neill's Supernaturalistic Technique. New Haven, Conn.: Yale University Press, 1969.

Voglino, Barbara. "Perverse Mind:" Eugene O'Neill's Struggle with Closure. Cranbury: Associated American Presses, 1999.

Wiles, Timothy. "Tammanyite, Progressive, and Anarchist: Political Communities in The Iceman Cometh." CLIO (1980).

\section{NOTES}

i. For a detailed study of the Christian symbolism in The Iceman Cometh and a comparison between Hickey and Jesus Christ, see Cyrus Day, Bogard 412 and Wiles 185. ii. Many of the characters have been identified with O'Neill's actual friends of that time. For a detailed discussion of this autobiographical element see Sheaffer's discussion of The Iceman Cometh, and Doris Alexander 12.

iii. Louis Broussard argues that the quietness of the atmosphere, if applied to O'Neill's career as a dramatist, reflects no less than his "abdication from his role as explorer after truth." He adds that "it is an attitude which finds symbolic reflection in the anarchist abandoned by Larry Slade. Somewhat like the Hairy Ape himself, O'Neill had gone slashing away at institutions, at the Church, at marriage, at materialism, capitalism, socialism, science - until there was none left to discard. The annihilistic state in which his method left him was indeed the 'last harbor,' where, all truths now having been proved false, man can either subsist on illusions produced by drunkenness or die" (Broussard 32-3).

iv. For a similar argument see Scheibler 168.

v. For more discussion on the party, see Scheibler 171-73, who discusses it in light of the grotesque tradition.

vi. Horst Frenz argues that Hickey's criminal act is the result not of hatred or vengeance, but of his inability to "return the love his wife had given him for so long," and elaborates that "it is the recognition of this weakness or inadequacy, his admission of the truth about himself, that brings about his crime" (Frenz 82). I do not think that Hickey is motivated by the recognition of his inadequacy but by the need to get rid of Evelyn as a reminder of his own imperfection. Thus, by murdering her, he thinks he 
could carry on his pipe dream of self-acceptance despite the recognition of his own inadequacy.

\section{RÉSUMÉS}

This paper analyzes Eugene O'Neill's advocation of the impossibility of salvation or reformation on both societal and individual levels as dramatized in The Iceman Cometh. The method the playwright uses is to have a group of derelict characters gather in an isolated place and put them under the spell of a savior, Hickey, who aspires to shape their lives according to his own vision. O'Neill's savior, however, proves to be a parody of a savior, who alienates the misfortunate group instead of saving it.

Hickey's brand of salvation leads to death as a means of terminating human life and negating spiritual values. This paper thus analyzes O'Neill's masterpiece as a dramatization of his pessimistic vision of the world as a lodge of the misfortunate, of human life as a nightmare, and of death as the only way out. The Iceman Cometh orchestrates no hope for man in modern times, but sings an elegy for the misbegotten and depicts the world as a morgue for death-in-life.

\section{INDEX}

Keywords : modernism alienation, salvation, Christian models, madness, Eugene O'Neill theatre, death in literature

\section{AUTEUR}

\section{MUFEED F. AL-ABDULLAH}

Mufeed F. Al-Abdullah, Dhofar University 